\title{
RANCANGAN SISTEM ELEKTRONIK KANBAN UNTUK MENINGKATKAN EFEKTIVITAS PRODUKSI JUST IN TIME
}

\author{
ZAHIDI PUTRA PUAR, M. TIRTANA SIREGAR ${ }^{2}$ \\ Program Studi Manajemen Logistik Industri Elektronika Politeknik APP Jakarta \\ E-mail: $\underline{\text { tirtana-s@kemenperin.go.id }}^{1}$
}

DOI Number : $\underline{\text { 10.30988/jmil.v1i1.11 }}$

\begin{abstract}
This research describes an electronic Kanban system development in order to replace conventional Kanban system. Many previous research conducted to optimize number of Kanban, however weaknesses still find when there is a change condition of production planning, therefore it must be re-optimization number of Kanban and it will takes time and costs. In current condition, the Company has implemented a manual Kanban system to support their Just In Time production system, but unfortunately it still find problems during implementation due to the system implemented using paper and manual recording. In this research, the electronic Kanban system (e-Kanban) is develop based on computer vision which combined with production systems condition in currently. E-Kanban system is a method to replace manual Kanban irregularity. Based on result through a scenario Master Production Schedule (MPS), Electronic Kanban system can deliver information effciently and effectively with improve 54\% compared with conventional systems and $32 \%$ compared with manual Kanban.
\end{abstract}

Keywords: Just In Time, Sistem Kanban, System production

\begin{abstract}
Abstrak
Judul Penelitian ini memaparkan pembangunan sistem elektronik Kanban untuk menggantikan sistem Kanban konvensional. Banyak penelitian yang dilakukan sebelumnya untuk mengoptimasi jumlah Kanban, akan tetapi kelemahan yang masih ditemui adalah apabila terjadi perubahan perencanaan produksi maka harus dilakukan optimasi ulang jumlah Kanban dan hal itu tentu saja memerlukan waktu dan biaya. Dalam perkembangannya, Perusahaan telah menerapkan sistem Kanban untuk mendukung sistem produksi Just In Time, namun masih saja ditemukan permasalahan yang terjadi dilapangan dikarenakan sistem yang diterapkan menggunakan kertas dan pencatatan manual. Pada penelitian ini sistem elektronik Kanban (e-Kanban) dibangun berbasis visi komputer yang digabung dengan sistem produksi yang kondisinya saat ini berjalan. Metode E-Kanban adalah metode untuk mengatasi ketidakteraturan Kanban manual. Berdasarkan pengujian yang menggunakan sebuah skenario Jadwal Induk Produksi (JIP) yang telah ditentukan didapati bahwa sistem elektronik Kanban dapat mengalirkan informasi secara efisien dan efektif dengan peningkatan $54 \%$ dibanding dengan sistem konvensional dan $32 \%$ dibanding dengan Kanban manual.
\end{abstract}

Kata kunci: Just In Time, Sistem Kanban, Sistem produksi

\section{PENDAHULUAN}

Seiring dengan perkembangan industri di tanah air, menyebabkan terjadinya persaingan yang cukup ketat antar perusahaan. Tuntutan globalisasi menuntut dunia industri untuk membangun profesionalisme yang mencakup keseluruhan sistem industri, 
sehingga industri dapat memahami konsep sistem produksi dalam performansi bisnis modern. Industri modern yang berada dalam pasar global yang sangat kompetitif menganut konsep produksi bukan sekedar sebagai aktivitas mentransformasikan input menjadi output, tetapi memandang konsep produksi sebagai aktivitas penciptaan nilai tambah (value added), untuk setiap aktivitas dalam proses produksi harus memberikan nilai tambah. Pemahaman terhadap nilai tambah dirasakan sangat penting, hal ini guna untuk menghindari pemborosan (waste) dalam setiap aktivitas produksi. Kualitas merupakan faktor dasar konsumen terhadap suatu jasa. Kualitas juga merupakan faktor utama yang membawa keberhasilan bisnis.(Parasuraman et.all,1985).

PT. Rekadaya Multi Adiprima adalah perusahaan yang bergerak di bidang manufaktur komponen otomotif dimana kegiatannya adalah memproduksi Insulator Assy Dash Panel dan Insulator Door Trim untuk industri kendaraan roda empat (4 wheels). Saat ini Perusahaan sudah menerapkan sistem Kanban untuk mendukung proses Just In Time nya pada salah satu lini produksi yaitu produksi karpet flet yang umumnya dipasang di interior mobil sebagai peredam suara.

Permasalahan yang sering dihadapi oleh PT. Rekadaya Multi Adiprima dalam menerapkan sistem Kanban manual adalah masih menggunakan catatan manual dan banyaknya penggunaan kertas, yang menyebabkan terkadang data tidak diperbarui setiap saat oleh petugas yang bekerja pada lini tersebut. Sehingga tidak terintegrasinya setiap lini departemen dalam menerapkan Kanban yang efektif dan efisien.
Proses penelitian ini merupakan suatu proses yang terdiri dari tahap yang saling terkait secara sistematik satu dengan lainnya. Hasil dari suatu tahap akan merupakan masukan bagi tahap selanjutnya, sehingga tahap sebelumnya akan sangat menentukan. Sementara itu, masing-masing tahap itu sendiri dari langkah-langkah penelitian yang akan menguraikan sistematika penelitian lebih mendetail.

\section{HASIL DAN PEMBAHASAN}

Hasil pengamatan sistem Kanban manual menunjukkan bahwa sistem Kanban yang digunakan di PT. Rekadaya Multi Adiprima adalah sistem Kanban tarik. Penentuan sistem Kanban tarik ini berdasarkan dari adanya perintah permintaan dari konsumen. PT. Rekadaya Multi Adiprima dalam melakukan sistem Kanban dikarenakan konsumennya juga memakai sistem Kanban, oleh karena itu sebagai pemasok, harus mendukung sistem yang digunakan oleh konsumennya. Berikut adalah alur sistem Kanban yang diterapkan oleh PT. Rekadaya Multi Adiprima :

\section{METODE PENELITIAN Identifikasi Permasalahan}




\begin{tabular}{|l|l|l|}
\hline Keterangan & Past & Current \\
Time & State & State \\
\hline Value Added & 160,45 & 160,45 \\
\hline Lead Time & 400,58 & 320,46 \\
menit & menit & menit \\
\hline WIP karpet Flet & 40 & 20 \\
\hline Inventory & 30 & 20 \\
Finish Good & & \\
\hline
\end{tabular}

Agile Software development merupakan salah satu metodelogi dalam pengembangan sebuah perangkat lunak (software). Kata Agile berarti bersifat cepat, ringan, bebas bergerak, waspada. Kata ini digunakan sebagai kata yang menggambarkan konsep model proses yang berbeda dari konsep model-model proses yang sudah ada. Dalam Agile Software Development interaksi dan personel lebih penting dari pada proses dan alat, software yang berfungsi lebih penting daripada dokumentasi yang lengkap, kolaborasi dengan klien lebih penting daripada negosiasi kontrak, dan sikap tanggap terhadap perubahan lebih penting daripada mengikuti rencana (Jim, 2002).

Aplikasi agile software yang digunakan dalam membuat e-kanban adalah piranti lunak axosoft, berikut tampilan awal piranti lunak axosoft.

Pada Axosoft membuat user baru sesuai dengan fungsinya, sehingga setiap user diberikan autoritas dalam

\section{DAFTAR PUSTAKA}

Agus Ristono, Sistem Produksi Tepat Waktu, edisi pertama, Yogyakarta : Graha Ilmu, 2010.

Celano, G., Costa, Antonio., Fichera, S. 2004. A Comparative Analysis of Sequencing Heuristics for Solving the Toyota Goal melakukan setiap proses, dan juga terdapat security role, dimana user dapat melihat menu-menu yang ada di axosoft.

Berdasarkan implementasi rancangan sistem elektronik Kanban, maka diperoleh perbandingan nilai efektivitas produksi karpet flet yang ditunjukkan pada gambar 4.10.

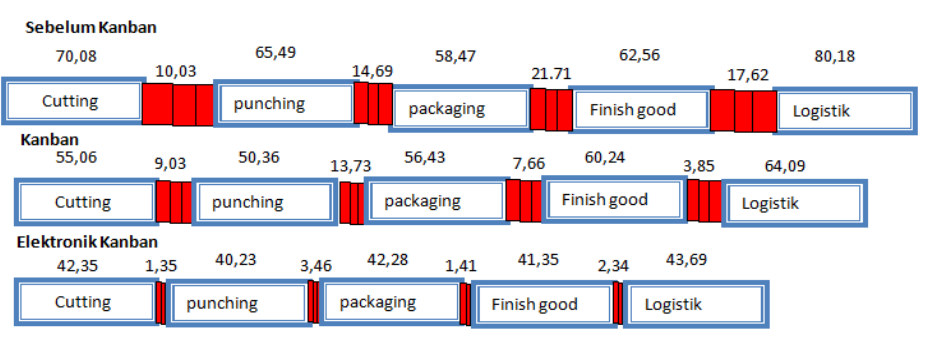

Gambar 4.10 Lead time past, current, future state

\section{KESIMPULAN}

Berdasarkan penelitian yang telah dilakukan dapat disimpulkan bahwa:

1. Mekanisme sistem Kanban yang diusulkan adalah sistem e-Kanban dengan menggunakan sistem agile software development. Sistem eKanban memberikan pengendalian sistem Just in Time yang efektif dengan lead time $54 \%$ lebih tinggi dibanding tidak menggunakan sistem Kanban dan $32 \%$ lebih tinggi dibanding dengan Kanban manual.

2. Rancangan dari sistem informasi usulan dengan e-Kanban akan mempermudah menginput data order dan menginput data Kanban yang dibutuhkan dalam proses produksi.

Chasing Problem. Int Robotics and Computer Integrated Manufacturing: 573581

Jim Highsmith, Agile Software Development Ecosystem, Addison-Wesley, 2002.

Lippolt, C.R \& Furmans, K. (2008). Sizing of Heijunka-controlled Production Systems with Unreliable Production Processes. in Page $\mid 73$ 
IFIP International Federation for Information Processing, Volume 257, Lean Business Systems and Beyond, Tomasz Koch, ed.; (Boston: Springer), pp. 11-19.

Monden, Yasuhiro, Sistem Produksi Toyota, Buku 1 dan 2, PT Pustaka Binaman Pressindo, Jakarta, 2010.

Monden, Yasuhiro, Toyota Production System: An Integrated Approach to Just-in-Time,
Fourth Edition, CRC Press Taylor \& Francis Group, 2012.

Ohno, Taiichi, Just-in-Time Dalam Sistem Produksi Toyota, PT Pustaka Binaman Pressindo, Jakarta, 1997

Parasuraman, et.al, 1985, Pelayanan Pelanggan yang Sempurna, Kunci Ilmu, Yogyakarta.

Pyzdek, Thomas. (2002). The Six Sigma Handbook : A Complete Guide for Green Belts,Black Belts, and Managers at All Level.. McGraw-Hill, New York. 